\title{
As influências teóricas e do contexto sociocultural no trabalho técnico científico de James Prescott Joule: Contribuições para a formação de professores de Física ${ }^{+}$
}

\author{
Wellington Pereira de Queirós ${ }^{1}$ \\ Universidade Federal do Mato Grosso do Sul \\ Campo Grande - MS \\ Roberto Nardi ${ }^{1}$ \\ Universidade Estadual Paulista \\ Bauru - SP \\ Demétrio Delizoicov Neto ${ }^{1}$ \\ Universidade Federal de Santa Catarina \\ Florianópolis - SC
}

\section{Resumo}

Descrevemos aqui resultados parciais de um estudo no qual procuramos desvelar as influências histórico-socioculturais que permearam o trabalho técnico-científico de James Prescott Joule e mostrar suas contribuições para a formação de professores de Física. Procuraremos responder a seguinte questão: Quais foram os elementos teóricos, sociais e culturais que influenciaram o trabalho de Joule? Nesse sentido, apresentamos um breve histórico do desenvolvimento da ciência no período da revolução industrial, bem como o desenvolvimento industrial da grande Manchester, em que Salford faz parte de sua região metropolitana cidade onde Joule nasceu e cresceu. Em seguida mostramos a importância e a influência cultural do entorno social e acadêmico de Joule e de elementos teóricos que influenciaram, sobretudo, os trabalhos sobre efeito Joule e o Equivalente Mecânico do Calor. A partir do estudo realizado, organizamos alguns apontamentos visando contribuir para a formação de professores.

\footnotetext{
${ }^{+}$Theoretical influences and the Socio-cultural Context in the Scientific Technical Work of James Prescott Joule: Contributions to the Formation of Physics Teachers

* Recebido: junho de 2018. Aceito: setembro de 2019.

${ }^{1}$ E-mails: wellington_fis@yahoo.com.br; r.nardi@unesp.br; demetrio.neto@ufsc.br
} 
Palavras-chave: Joule; Natureza da Ciência; Formação de Professores.

\begin{abstract}
We describe here partial outcomes of a study in which we seek to unveil the historical-sociocultural influences that permeated the technical-scientific work of James Prescott Joule and show his contributions to the physics teachers training. We tried to answer the following question: What were the theoretical, social and cultural elements that influenced Joule's work? In this sense, we present a brief history of the development of science in the period of the Industrial Revolution, as well as the industrial development of Greater Manchester, in which Salford is part of its metropolitan region, city where Joule was born and grew up. Next we show the importance and the cultural influence of the social and academic environment of Joule and of theoretical elements that influenced, mainly, the works on Joule effect and the mechanical equivalent of the heat. From the study carried out, we organized some notes aimed at contributing to the teachers' training.
\end{abstract}

Keywords: Joule; Nature of Science; Teacher Training.

\title{
I. Introdução
}

No contexto brasileiro e internacional, vários autores (SILVA; MOURA, 2008; PARASKEVOPOULOU; KOLIOPOULOS, 2011; EASTWOOD et al., 2012; FERREIRA ; MORAES, 2013; LEDERMAN; ANTINK ; BARTOS, 2014; QUEIRÓS; NARDI; DELIZOICOV, 2014; MARTINS, 2015; FONSECA et. al., 2017; GATTI; NARDI, 2016) defendem uma discussão da natureza da ciência na educação em Ciências, na divulgação científica, no ensino básico e na formação de professores com o objetivo de possibilitar um maior entendimento do que é ciência para os estudantes.

Na formação de professores, Matthews (1994) defende a abordagem de natureza da ciência na formação de professores, a fim de garantir três competências básicas: (i) O conhecimento e a apreciação da ciência que ensinam; (ii) A compreensão da História e filosofia da ciência; (iii) A formação teórica que fundamente suas atividades em sala de aula. Outros autores denunciam a visão distorcida da natureza do conhecimento científico presente, muitas vezes, nas práticas de ensino de professores, evidenciando fortemente o caráter empiristaindutivista da ciência e a disponibilidade/indisponibilidade de materiais de ensino, centradas em uma discussão da natureza do conhecimento científico (GIL-PÉREZ et al., 2001).

A sinalização para a discussão da natureza da ciência também é feita nos documentos oficiais de formação de professores como, por exemplo, as Diretrizes Curriculares para os 
cursos de Física (CNE/CES 1304/2001); a indicação é feita tanto para os cursos de bacharelado quanto para os de licenciatura em Física: "Desenvolver uma ética de atuação profissional e a consequente responsabilidade social, compreendendo a Ciência como conhecimento histórico, desenvolvido em diferentes contextos sócio-políticos, culturais e econômicos" (CNE/CES 1304, 2001, p. 4)

Nesse sentido, o presente trabalho visa problematizar equívocos sobre a natureza da ciência, muitas vezes presentes em materiais didáticos que interferem na formação de professores, tais como: a) visão descontextualizada e neutra da produção do conhecimento científico; b) A concepção empirista-indutivista da ciência de que a observação precede a teoria. Para tanto, apresentamos, nessa comunicação, parte dos resultados de um estudo HistóricoFilosófico-Sociológico sobre os trabalhos de James Prescott Joule (1818-1889) realizado em uma tese de doutorado (QUEIRÓS, 2012).

Assim, expomos, no presente artigo, os aspectos históricos e sociais que permearam o trabalho de Joule, com a apresentação de um breve histórico do desenvolvimento da ciência, no período da revolução industrial; bem como, o desenvolvimento industrial de Manchester, grande metrópole, da qual a cidade de Salford faz parte, e é onde Joule nasceu e cresceu. Em seguida, mostramos a importância e a influência do contexto cultural, destacando a preocupação de Joule com o funcionamento da cervejaria de propriedade de sua família e de outros elementos teóricos, da prática técnico-científica, que influenciaram os seus principais trabalhos: o famoso efeito Joule e o Equivalente Mecânico do Calor. Por fim, apontaremos as possíveis contribuições desse estudo para a formação de professores de Física. Neste sentido, no presente trabalho, procuraremos responder a seguinte questão: Quais foram os elementos teóricos, sociais e culturais que influenciaram o trabalho de Joule?

Assim, apesar de não ter a pretensão de fazer uma leitura fleckiana dos condicionantes que influenciaram o trabalho de Joule, o presente estudo está em sintonia com a concepção epistemológica de Ludwik Fleck (2010). Isto ocorre devido a sua teoria da ciência, por meio da categoria, estilo de pensamento, permitir uma análise de um episódio científico, que estabelece relações entre, particularmente, as dimensões científica, social e política presentes em um determinado período histórico. São vários os trabalhos que apresentam análises históricoepistemológicas sobre outros episódios da História da Ciência, que têm como base categorias analíticas oriundas da obra desse autor, como a história da circulação sanguínea (CASTILHO; CARNEIRO; DELIZOICOV, 2004); a história da proposição do modelo do DNA (SHEID; FERRARI; DELIZOICOV, 2005); a produção técnico-científica de James Prescott Joule (QUEIRÓS; NARDI; DELIZOICOV, 2014); a proposição do quantum de energia por Planck e seus desdobramentos (DELIZOICOV, 2009).

\section{A Ciência e a revolução industrial na Inglaterra: O contexto de Manchester e Salford}

De acordo com Soares (2001), a visão mecanicista de mundo, no século XVIII, já tinha sido consagrada pela maioria dos intelectuais ingleses e franceses. Tal perspectiva contri- 
buiu enormemente para a transformação tecnológica e social expressa na revolução Industrial: "A disseminação do Mecanicismo nos meios técnicos e industriais, por sua vez, fundamentou a ideia de que o mundo da produção e, em particular, da produção industrial, poderia também se submeter à lógica da mecanização" (SOARES, 2001, p. 104).

O mecanicismo newtoniano influenciou a construção do conhecimento científico nos séculos XVIII e exerce influência até os dias atuais. Notamos este fato, principalmente, no período correspondente a revolução industrial, em que técnicos, engenheiros, mecânicos utilizaram-se da Física newtoniana e dos princípios da Ciência Moderna para a construção de máquinas, que contribuíram para um novo modelo de organização técnico industrial (SOARES, 2001). Esta nova visão de mundo foi altamente disseminada nas academias técnico científicas da época, entre elas a Sociedade literária e filosófica de Manchester, da qual James Prescott Joule fez parte (CARDWELL, 1989; STTEFENS, 1979). Assim, é importante contextualizarmos $^{2}$ o trabalho de Joule para entendermos as influências que permearam os seus estudos, principalmente durante o período da revolução industrial.

Segundo Hobsbawm (1977, p. 51), apesar das controvérsias entre os historiadores, uma investigação criteriosa levou a maioria dos estudiosos a entender que a revolução industrial surgiu na década de 1780, na Grã-Bretanha. Naquela década, houve uma transformação rápida dos bens de consumo e das relações de trabalho, fazendo a economia crescer substancialmente. Para o autor, não faz sentido perguntar quando ela se completou, uma vez que ainda prossegue, assumindo significados distintos nos diferentes momentos da História da Humanidade.

Uma das razões para a revolução industrial ter começado na Grã-Bretanha foi porque, tradicionalmente, mesmo com a monarquia, a política da Inglaterra voltou-se para o desenvolvimento econômico; havia uma quantidade significativa de proprietários de terras com forte interesse comercial, portanto, o homem era visto mais como um comerciante do que um simples camponês, que se dedicava à agricultura de subsistência. As relações de campesinato na Inglaterra eram diferentes das que aconteciam na França, na Alemanha e na Rússia, já que as atividades agrícolas estavam predominantemente voltadas para o mercado. O setor agrícola já estava preparado para exercer o papel do processo de industrialização, em três funções fundamentais:

Aumentar a produção e a produtividade de modo a alimentar uma população não agrícola em rápido crescimento. Fornecer um grande e crescente excedente de recrutas em potencial para as cidades e as indústrias. Fornecer um mecanismo para o

\footnotetext{
2 Nesse processo de descrição do contexto industrial vivido por Joule, utilizaremos, aqui, como uma das principais referências o trabalho do historiador Eric Hobsbawm intitulado: A Era das Revoluções. Soares (2001) alerta que Hobsbawm e outros historiadores praticamente não estabeleceram relações entre as instituições de ensino e as invenções técnicas que caracterizaram o processo de emergência da revolução industrial. Concordamos com o autor, no entanto, entendemos que, do ponto de vista da História da revolução industrial e a descrição do desenvolvimento da ciência e da técnica da época, a obra do Hobsbawm, acompanhada de outras referências de historiadores, dá conta de subsidiar, no presente estudo, parte da contextualização histórica, social e econômica, que permeou a vida e obra de James Prescott Joule.
} 
acúmulo de capital a ser usado nos setores mais modernos da economia (HOBSBAWM, 1977, p. 54-55).

A infraestrutura necessária para se adaptar à nova realidade da industrialização já estava sendo feita com a construção de navios, portos, estradas e novos meios de transportes. A finalidade básica era facilitar o escoamento do excedente de produção, a fim de aumentar as exportações e garantir o aumento do capital interno. Entretanto, ainda no século XVIII, a maior parte da expansão industrial não se caracterizou por um sistema fabril mecanizado, mas apenas atendia à demanda do mercado existente. Um exemplo foi a indústria de pequeno porte, como as produtoras de objetos de metal para uso doméstico, que se expandiu na Inglaterra central e na região de Yorkshire.

A primeira indústria a se expandir com a revolução industrial foi a de algodão, já que até a década de 1830, era a única indústria britânica em que predominava a fábrica ou o "engenho". A máquina a vapor e outros maquinários tornaram a "indústria" e a "fábrica", mais significativa e lucrativa, que pertencia às áreas algodoeiras do Reino Unido.

Em outros setores como mercadorias de consumo, produtos têxteis, alimentos e bebidas, cerâmicas e outros produtos de uso doméstico, a revolução industrial fez-se presente, principalmente, no crescimento das cidades. Em termos de pessoal, estas indústrias empregavam muito menos pessoas do que as indústrias algodoeiras. Um exemplo eram as indústrias cervejeiras; um negócio técnico e, cientificamente, muito mais avançado e mecanizado que revolucionou muito antes da indústria algodoeira e afetou muito pouco a economia na época. Já a indústria algodoeira provocou o surgimento de outras inovações e indústrias como a de máquinas, eletrificação industrial, transportes e inovações químicas. Estas indústrias do ramo têxtil contribuíram para o crescimento econômico da Grã-Bretanha, até a década de 1830 (HOBSBAWM, 1977, p.63-64).

Outro tipo de indústria que se destacou foi a metalurgia, no processo de obtenção de ferro e aço. Tal indústria teve grande força, principalmente, com a construção de ferrovias, motivadas pela mineração de carvão, que foi a principal fonte de energia industrial do século XIX. A produção de carvão foi impulsionada pelo crescimento das cidades, desde o final do século XVI. Em princípios do século XVIII, a indústria de carvão era moderna, principalmente, com o uso da máquina a vapor na região da Cornuália (HOBSBAWM, 1977, p. 70-75).

O avanço britânico, no início da revolução industrial, não ocorreu devido à superioridade tecnológica e científica, uma vez que nas ciências naturais, os franceses estavam mais avançados. A Revolução Francesa foi incentivadora do desenvolvimento científico, principalmente, nas áreas de Física, Matemática e Ciências Sociais. Um exemplo foi o geômetra e engenheiro Lazare Carnot (1753-1823), que também era ministro da marinha, que se dedicava à produção bélica e ficou à frente da organização militar (HOBSBAWM, 1977, p. 52, 384).

Já na Inglaterra, as principais indústrias foram as têxteis, de algodão, de carvão, do ferro, das ferrovias e da construção de navios mercantes e representaram os avanços mais transcendentais do século XIX (BERNAL, 1973). Além disso, a imensa riqueza da Inglaterra 
produzida pela revolução Industrial tornou possível a criação de laboratórios particulares, como o de Henry Cavendish (1731-1810) e o de James Prescott Joule (1818-1889). Houve também uma pressão geral de intelectuais da classe média por uma educação técnica e científica para obtenção de bons resultados; Associações, Sociedades e Institutos de ciências foram criados. Benjamin Thompson (1753-1814), o conde Rumford, fundou a instituição Real, em 1799, dando possibilidades para o desenvolvimento da ciência experimental, principalmente auxiliando os estudos de Humphry Davy (1778-1829) e Michael Faraday (1791-1867). A criação da Sociedade Lunar de Birmingham, da Sociedade Filosófica e Literária de Manchester, do Instituto Mecânico de Londres, da Universidade de Londres e da Associação Britânica para o Progresso da Ciência tiveram apoio de industriais dos estados ingleses (HOBSBAWM, 1977, p. 386).

Não podemos deixar de mencionar, no entanto, que o processo de industrialização passou por crises, como por exemplo, a diminuição no crescimento industrial, na década de 1830 e início de 1840. Além disso, as relações de trabalho ficaram cada vez mais complexas, com o surgimento de problemas: o primeiro foi a saída do homem do campo para a cidade, que provocou um aumento da população urbana; além do rápido aumento geral da população, houve o aumento no fornecimento de alimentos, principalmente da agricultura doméstica, ou seja, uma revolução agrícola; na indústria, a dificuldade era conseguir trabalhadores qualificados, pois a maioria vinha do campo sem, praticamente, nenhuma instrução para trabalhar com maquinaria, além da constante exploração de mulheres e crianças, principalmente, nos engenhos de algodão. Esses problemas e crises levaram a revoltas sociais, como o movimento das quebras das máquinas pelos trabalhadores da indústria (HOBSBAWM, 1977).

Apesar desses problemas apontados, a expansão da revolução industrial inglesa contribuiu para o avanço industrial e científico em outros países, já que permitiu aos cientistas permanecerem em seu país, saindo apenas para aperfeiçoamento ou para ministrar conferências. A comunicação entre os pares ocorria, basicamente, através dos periódicos especializados, dos quais podemos citar alguns: as Atas da Real Sociedade (1831), as Comptes Rendues de L'Academie dês Sciences (1837), as Atas da Sociedade Filosófica Americana (1838), ou as novas revistas especializadas tais como o Journal fur Reine und Angewandte Mathematick, de Grelle, ou os Anais de Química e Física (1797) (HOBSBAWM, 1977, p. 386-387).

Com relação ao desenvolvimento das Ciências, no período da revolução industrial, de acordo com Hobsbawm (1977), as ciências físicas clássicas não sofreram revolução, seguiram basicamente o paradigma newtoniano ou continuaram as linhas de pesquisa do século XVIII. Um dos mais importantes campos abertos foi o da eletricidade e suas conexões com outras áreas do conhecimento: os estudos de bioeletricidade realizados por Luigi Galvani (1737-1798); a conexão entre eletricidade e magnetismo por Hans Christian Oersted (17771851); estudos de bioeletricidade e a construção da bateria por Alessandro Volta (1745-1827) em 1800. 
O estudo da eletricidade veio constituir uma inesgotável linha de pesquisa de novos e apaixonantes fenômenos que serviram de verdadeiro estímulo para experimentos posteriores, do tipo qualitativo, culminando no desenvolvimento da teoria eletromagnética de Maxwell. Tal teoria foi uma tentativa de matematizar os fenômenos estudados por Faraday e estabelecer interconexões matemáticas entre as teorias de Fresnel e de Gauss, bem como entre os sistemas de unidades elétricas e magnéticas de Weber (BERNAL, 1973, p. 28-29).

Outro avanço importante, de todas as sínteses teóricas, foi a desenvolvimento das leis da termodinâmica e as relações entre calor e energia. De acordo com Bernal (1973, p. 23), os desenvolvimentos mais importantes da Física, no século XIX, foram a Teoria da Conservação da Energia e a interconexão de suas distintas formas; ou seja, as ciências da Termodinâmica e a Eletrodinâmica se inspiraram no estudo das fontes utilitárias de energia e nasceram das necessidades de transporte e comunicação, apesar de que sua utilização mais abrangente, como base de uma indústria química e elétrica racional, aconteceu só no século XX.

De acordo com Knight (1986) apesar de que, no século XIX, a especialização nas Ciências era cada vais mais célere, a instauração do princípio da conservação da energia permitiu a unificação de conceitos e subsidiou a explicação de uma gama de fenômenos em áreas como eletricidade e mecânica, aparentemente desconexas. A conservação da energia deu uma boa razão para colocar todas as ciências sob um único guarda-chuva, ou seja, eletricidade, magnetismo, ótica, calor e mecânica agora estavam todas juntas; a nova ciência da físicoquímica surgiu para estudar a energia e a taxa de mudanças químicas. Para o autor a conservação da energia era comparável à teoria da evolução, ou seja, como princípio organizador das ciências, que abriu novas portas e indicou novas relações entre a Ciência e a Tecnologia.

Ainda de acordo com Knight (1986) e Bernal (1973), o começo do século XIX representou a união da Mecânica com a Astronomia; segundo as concepções de Newton e Galileu, a ciência acadêmica continuou sendo preponderante. A expansão da Física Newtoniana é explícita nos trabalhos de cientistas como Lagrange, Fourier, Hamilton e Gauss, na evolução da linguagem matemática para a descrição dos fenômenos físicos de caráter mais geral, como a eletricidade e o magnetismo na teoria cinética dos gases e nos fundamentos da termodinâmica.

Segundo Bernal (1973), o desenvolvimento da primeira e segunda lei da termodinâmica beneficiou a indústria, que tomou forma com o motor de combustão interna e os primeiros experimentos com as técnicas de refrigeração. Estes dois ramos, o Eletromagnetismo e a Termodinâmica, no século XIX, desenvolveram-se e ganharam novas formulações da Física atômica e aglutinaram-se nas generalizações de Einstein e Max Planck sobre a teoria quântica, no século XX.

Com relação ao desenvolvimento da Química, de acordo com Knight (1986), esta foi a ciência que mais sofreu influência da revolução industrial, principalmente com a indústria têxtil; os processos de tingimento e branqueamento eram requisitados, e, seus criadores eram homens práticos, como John Dalton (1766-1844), da sociedade Filosófica e Literária de Man- 
chester e Joseph Priestley (1733-1804) da Sociedade Lunar de Birmingham. A Química, como a Física, foi uma ciência fortemente francesa, já que Antoine Lavoisier (1743-1794), um dos seus principais representantes, publicou o Tratado Elementar de Química, no próprio ano da revolução.

Os principais avanços, antes de 1789, consistiram em estabelecer uma ordem elementar no emaranhado de experiências empíricas, através da elucidação de certos processos químicos fundamentais, como o oxigênio. A teoria atômica de John Dalton (1766-1844) tornou possível a invenção da fórmula química, abrindo um vasto campo para o estudo de estruturas químicas. Outros episódios históricos importantes da Química foram o estudo desenvolvido por Antoine Lavoisier, de que a respiração é uma forma de combustão do oxigênio, e, a síntese da Ureia, em 1828, por Friedrich Woehler (1800-1882) que abriram um vasto campo para a Química Orgânica.

Já o desenvolvimento da engenharia foi caracterizado pelo avanço da indústria metalúrgica, que alimentou a indústria mecânica e a construção de máquinas. Um dos principais representantes deste ramo foi James Watt (1736-1819), o primeiro construtor profissional de máquinas. A sua associação com o industrial Matthew Boulton (1728-1809), em 1775, sinalizou a fundação da primeira empresa de construção de maquinaria (HOBSBAWM, 1977).

A indústria que estava nascendo tinha como objetivo a aplicação diversificada da força expansiva do vapor, a nova energia motriz gerada pela máquina a vapor. Eram necessários, portanto, o seu aperfeiçoamento e o melhoramento da resistência dos materiais e a técnica dos métodos de trabalho, e, para que isto ocorresse, deveriam acontecer várias melhorias na máquina a vapor até chegar à turbina a vapor, ocorrida no final do século XIX.

Um exemplo da melhoria das técnicas e de métodos de trabalho foi a conexão entre desenhistas e engenheiros. O desenho na engenharia foi uma característica essencial na revolução industrial, quando entrou no palco de obras de grande escala; é, portanto, um elemento característico da era científica do século XIX (KNIGHT,1986). Contemporâneo de Watt, Gaspard Monge (1746-1818), em 1795, publicou a descrição geométrica que foi a base para o desenho da engenharia moderna, que auxiliou a elaboração de projetos transcritos no papel e facilitou a sua execução por muitos trabalhadores de fábricas e oficinas distantes. Um exemplo, deste desenvolvimento na engenharia, foram os desenhos cuidadosos da máquina a vapor realizados por James Watt (KNIGHT,1986).

Inicialmente, os projetos e desenvolvimento de máquinas e peças eram feitos de forma artesanal, realizados por inventores amadores e entusiastas. Entretanto, houve iniciativas de construção de máquinas capazes de produzir uma força imensamente superior ao do homem, como a prensa hidráulica; esta contribuiu para o nascimento da engenharia pesada, combinada com a necessidade de barcos a vapor e, mais tarde, armas e navios de ferro blindados, que se tornaram uma lucrativa especialidade.

O progresso da indústria pesada foi viável, graças aos procedimentos para a fabricação de aço a baixo custo. Isto deu uma vantajosa posição a um reduzido número de empresas 
na Inglaterra, Alemanha, França e Estados Unidos, que tinham grande poder, principalmente, para financiar sua própria investigação, em especial no campo da turbina a vapor. A tendência geral da indústria mecânica foi a de constituir-se em uma atividade independente da vida acadêmica (BERNAL, 1979).

No campo da Biologia, a evidência de que todas as coisas vivas eram compostas de múltiplas células, feita por Matthias Jakob Schleiden (1804-1881) e Theodor Schwann (18101882), estabeleceu uma espécie de equivalência da teoria atômica para a Biologia, entretanto os campos da biofísica e da bioquímica ainda estavam longe de amadurecerem (HOBSBAWM, 1977, p. 388-389). Segundo Bernal (1973, p. 31), as investigações de Hermann Ludwig Ferdinand Von Helmholtz (1821-1894) sobre a fisiologia dos sentidos constituem exemplos da conexão entre as ciências físicas e biológicas, em meados do século XIX, sendo talvez a maior integração entre as duas ciências, naquela época.

No campo da Matemática, houve praticamente uma verdadeira revolução, em especial na Geometria. As teorias de Nikolai Lobachevsky (1792-1856) e do húngaro János Bolyai (1802-1860) propuseram uma geometria, muito além da geometria euclidiana que contribuiu muito para o campo das pesquisas na área de Matemática e Física. Estas teorias representaram um ato de audácia intelectual, comparado à ruptura do modelo geocêntrico para o heliocêntrico. Nesse período, foi crescente a aplicação de métodos matemáticos à sociedade e uma maior proximidade das ciências sociais às ciências físicas; houve, também, um grande desenvolvimento da ciência estatística, na interpretação do crescimento e desenvolvimento das populações humanas (HOBSBAWM, 1977, p. 389-393).

No campo das Ciências Sociais, destaca-se a criação da Sociologia por Augusto Comte; a criação da História como uma disciplina acadêmica empolgou vários pesquisadores a escrever e interpretar o passado de vários países, dentre eles, destacam-se Nikolai Karamzin (1766-1826), na Rússia, Erik Gustaf Geijer (1783-1847), na Suécia, os fundadores da historiografia em seus países. Nesse período, a História deixa de ser apenas relato cronológico para uma sucessão lógica de acontecimentos. Estes desenvolvimentos estão intrinsecamente atrelados às revoluções industrial e francesa (HOBSBAWM, 1977, p. 392-395).

No campo da Geologia e da Biologia, os problemas mais preocupantes eram, respectivamente, como explicar a evolução da Terra, a formação da vida e a evolução das espécies. A revolução industrial parece ter contribuído para a investigação e elucidação destas questões. O estudioso inglês William Smith (1769-1839), descobriu por meio das escavações industriais na década de 1790, que a sucessão histórica das camadas da Terra, podia ser mais convenientemente datada pelos seus fósseis característicos. Na década de 1830, teorias sobre a evolução ganharam um importante papel com a publicação da famosa obra Princípios de Geologia de Charles Lyell (1797-1875) (HOBSBAWM, 1977).

Enquanto as teorias da evolução engatinhavam, as teorias sobre evolução social sofreram vários progressos, como a Teoria da Evolução Social de Karl Marx (1818-1883) e Friedrich Engels (1820-1895) e as teorias da raça. O mesmo ocorria em outros campos, como 
a Antropologia e Psicologia, já que a maioria destas Ciências Sociais buscava uma explicação para as diferenças sociais humanas, em termos de meio ambiente, organização econômica e outros fatores igualmente relevantes (HOBSBAWM, 1977, p. 393-400).

De acordo com Hobsbawm (1977), essas mudanças no campo das ciências estão diretamente relacionadas à revolução industrial e a Francesa. Os problemas reivindicados pela indústria, como o da máquina a vapor, levaram vários cientistas a tentarem aperfeiçoá-la, dentre eles Nicolas Léonard Sadi Carnot (1796-1832), que muito contribuiu para o seu desenvolvimento. $\mathrm{O}$ grande incentivo para engenheiros e industriais na exploração das minas deu grande impulso à pesquisa em Geologia, pois a análise dos recursos minerais proporcionou, aos químicos, inúmeros compostos inorgânicos. E, assim nesta direção, a Metalurgia, as Artes Têxteis, as indústrias de iluminação a gás, produtos químicos e a agricultura estimularam os trabalhos de vários cientistas.

Diante da apresentação histórica realizada podemos compreender que as relações entre indústria e a construção das várias invenções provenientes do conhecimento sistematizado, durante o século XIX, foram mútuas. Duas tendências principais e complementares colocamse em evidência; de um lado, está o estudo científico de procedimentos industriais já estabelecidos com o uso da máquina a vapor e a fabricação do ferro, que conduziram a novas generalizações científicas, como a conservação da energia e a física da radiação; por outro lado, uma série de conhecimentos científicos nos campos da química e da eletricidade propiciou o desenvolvimento de novas indústrias como a telegráfica e a de corantes sintéticos.

Os laços entre a indústria e a ciência tinham um caráter muito mais esporádico e particularista, como aconteceu com James Watt, recebendo apoio do industrial Bolton. O desenvolvimento da técnica sem um conhecimento científico profundo, neste período, foi grande, apesar de que havia uma movimentação para uma sistematização do conhecimento e institucionalização da ciência de forma independente das aplicações práticas (BERNAL, 1979, p. 4548); isto não impediu que alguns cientistas desenvolvessem seu trabalho com uma preocupação de aplicação técnica.

Com a revolução industrial, Manchester ${ }^{3}$ tornou-se uma grande cidade industrial. A população quadruplicou e migraram para a cidade pessoas de vários lugares da Inglaterra e de

\footnotetext{
3 Manchester, em meados do século XVIII, era uma cidade pequena, agradável e próspera. Situada a leste do rio Irwell, é cortada por riachos de trutas, o Irk e Tib e ladeada ao sul pelo rio Medlock, um afluente do Irwell. Era uma cidade que refletia um passado rural, evidenciada pelos nomes das ruas: rua do mercado, rua da fonte, rua do banco. A população de Manchester e sua cidade próxima, Salford, do outro lado de Irwell, eram, aproximadamente, de 20.000 habitantes.

Ao norte do centro da cidade, ficava o colegiado da igreja (agora a catedral) juntamente com a escola de Chetham, que possuía uma das bibliotecas pública mais antiga do Reino Unido e uma das principais escolas de música da Inglaterra. A região sudoeste da cidade possuía casas elegantes ocupadas por ricos comerciantes, advogados e, particularmente, por cirurgiões e médicos, que se uniram e formaram a sociedade Literária e Filosófica de Manchester, como foi chamada em 1781. Em 1785, publicaram o seu primeiro jornal, o Memoirs and Proceedings of the Manchester Literary and Philosophical Society, que é considerado o mais velho periódico científico do Reino Unido, depois do Philosophical Transactions of the Royal Society.

Ao oeste e sul de Manchester, as ricas terras agrícolas de Lancashire e Cheshire possuíam grandes pomares. Devido a seus rios e córregos que fluem para oeste, o Mersey e o Irwell com seus afluentes, Irk, Roch, Medlock,
} 
outros países. Alguns eram camponeses, ou sem terras, trabalhadores como ferreiros, carpinteiros, serralheiros com habilidades práticas que poderiam fazê-los ganhar bons salários em novas usinas, fundições e oficinas. Para a maioria dos imigrantes, as fábricas ofereceram emprego, salário mínimo e vida livre (CARDWELL, 1989).

Infelizmente, Manchester não estava equipada para lidar com o enorme aumento da população; as condições de habitação eram caóticas, não havia praticamente nenhum planejamento para a saúde pública, abastecimento de água ou esgoto. Moradias foram criadas em uma escala sem precedentes, resultando em um aumento das taxas de mortalidade. Engels residiu nesta cidade e sua visão ajudou a mudar o curso da história.

Segundo Cardwell (1989), há uma distorção dos romancistas, de que existia uma grande diferença entre uma classe de capitalistas gananciosos e impiedosos e uma grande massa de explorados sofrendo com salários escravos. As usinas e fábricas empregaram uma grande classe de homens altamente qualificados como montadores, torneiros, desenhistas, caldeireiros que estavam orgulhosos e sabiam o quão eram importantes para as novas indústrias. A existência desta larga classe foi confirmada pelo sucesso da Instituição Mecânica de Manchester fundada em 1824, que desde o início, foi uma das maiores do país, sendo de tamanho comparável somente a de Leeds, Liverpool e Londres.

Com o processo de mecanização, os homens considerados semiqualificados, como os tecelões de teares manuais, depararam-se com suas vidas destruídas pelas novas máquinas, quase sem possibilidades de emprego e os que estavam empregados tinham péssimas condições de trabalho nas fábricas. Estas condições provocaram momentos de tensão, surgindo manifestações, que foram fortemente reprimidas pelos militares. A atuação dos militares provocou um dos massacres mais conhecidos de Manchester, o massacre de Peterloo, que ganhou um lugar na história social e política britânica (CARDWELL, 1989).

O massacre de Peterloo, porém, não travou o crescimento de Manchester. Os pobres continuaram à procura de trabalho, os ambiciosos em busca de fortunas e os hábeis procurando melhores oportunidades. Um grupo, particularmente interessante, foi composto por homens com habilidades excepcionais que vieram de outros países; a primeira leva veio da Escócia, país com instituições de ensino superior e uma tradição de exportador de talentos. Em seguida, dos estados alemães, cujo ensino melhorou rapidamente, no século XIX, até que foi

\footnotetext{
Tame, Bollim, Goyt, que nunca secavam e ainda os ventos do Oceano Atlântico contribuíram para Manchester e Salford terem um clima úmido médio. Tudo isto favoreceu o crescimento da indústria têxtil de algodão.

Manchester era uma cidade sem muita expressão política nas grandes questões da Igreja e do Estado. As primeiras mudanças começaram a ocorrer em meados do século XVIII, com a construção de canais como o canal Bridgewater, ligando as minas de carvão do duque de Bridgewater em Worsley, oito milhas a oeste de Manchester até Castlefield, justamente ao sul da cidade. Com a vinda de outras indústrias para Manchester, a construção de canais foi ampliada o que ligou Manchester ao Mar e a outras cidades da Inglaterra como Liverpool. Em comparação com as rodovias, o transporte nos canais foi lento, mas foi barato, confiável e poderia cooperar com as cargas pesadas e volumosas.

A construção da rede do canal começou a partir de Manchester, mas não teve conexão imediata ou direta com a transformação contemporânea da indústria têxtil, que tinha começado com a patente da máquina de tear de $\mathrm{Ri}$ chard Arkwright, de 1769 (CARDWELL, 1989).
} 
comumente aceito como o melhor do mundo. Eles vieram da Suíça e Áustria-Hungria e de outras partes de Europa oriental, onde tiranias arcaicas e religiosas e perseguições raciais eram endêmicas; também vieram da Itália, trazendo as boas habilidades dos italianos (CARDWELL, 1989).

Além daqueles atraídos pelas novas indústrias revolucionárias, havia oportunidades para pessoas comuns, como comerciantes e similares que iam onde havia grandes mercados. Manchester era um mercado grande e crescia rapidamente. Uma ponte sobre o rio Irwell foi construída de modo que a rua Bailey New tornou-se uma ligação direta entre Manchester e Salford. Não era uma rua da moda, como as ruas Mosley e Portland, pois fora construída uma prisão ao lado da cervejaria. Os moradores eram comerciantes, artesãos, lojistas, advogados entre outros; isto caracterizou o ambiente comercial e industrial da nova Manchester. Era também usual para os fabricantes, até mesmo de grandes empresas, viver ao lado de seus moinhos ou fábricas. No centro da cidade tinha a Rua Nova Bailey, que dava acesso à ponte sobre o rio Irwell que facilitava a passagem de barcos ou balsas de passageiros que prestavam serviços para lugares tão distantes como Runcorn, Widnes, Warrington, Bolton, Wigan e Worsley. O sistema de canal, rapidamente desenvolvido em conjunto com os rios navegáveis de Lancashire e Cheshire, formou uma rede de tráfego de passageiros, bem como de mercadorias. Entre as ruas Grosvenor e New Bailey, foi fundada a Instituição Mecânica de Manchester, na rua Cooper, perto da moderna Câmara Municipal e Biblioteca Central. Espalhadas em volta desta área central, estabeleceram-se numerosas fábricas, fundições e oficinas, como fábrica de tecidos emborrachados impermeáveis, fundição de metais, fábricas de máquinas a vapor, oficinas independentes, fábricas de instrumentos e outras (CARDWELL, 1989).

Uma das famílias atraídas pelo mercado de Manchester foi a família Joule. O avô de Joule, William Joule (1745-1799), estabeleceu uma fábrica de cerveja na Rua New Bridge (logo a ser chamada de rua New Bailey); antes de 1788, tinha sido dono de uma pousada em Youlgreave, em Derbyshire. William Joule, nasceu em 1745, em Youlgreave. Ele e sua esposa Martha tiveram seis filhos e estabeleceram um estilo de vida confortável e uma próspera cervejaria em Salford para deixar a seus herdeiros; o obituário da época declarou que era um homem generoso e teve sucesso nos negócios. Em 1798, tinha uma máquina a vapor trabalhando na fábrica de cerveja, que estava ao lado de sua casa. Somente grandes cervejeiras podiam ter máquinas a vapor e, em 1829, foi descrita como o maior negócio da cidade (CARDWELL, 1989).

Segundo Cardwell (1989), depois que William Joule faleceu em 1799, o negócio continuou a ser conhecido como William Joule \& Filho nas mãos da sua viúva, Martha, e pelo seu filho mais velho James que tinha apenas vinte anos, em 1799. Quatro filhos de William morreram antes de 1812 e James morreu em 1816, deixando apenas Benjamin, o segundo filho, nascido em 1784, que herdou os negócios. Benjamim casou-se com Alice Prescott, filha de Thomas Prescott, de Wigan e sua esposa, Grace, nascida Bradshaw. Eles tiveram sete filhos. Os dois primeiros, que eram meninos, morreram na infância. O primeiro a sobreviver até 
a maturidade foi Benjamim filho, nascido em 1817. Em seguida nasceu James Prescott Joule, na véspera do Natal de 1818; Alice em 1820; Mary em1823 e John Arthur, 1824.

\section{A vida de James Prescott Joule}

Segundo Rosenfeld (1952), não é possível compreender o trabalho de James Prescott Joule, sem colocá-lo no contexto social adequado. Para o autor, o fato é que uma análise do trabalho de Joule, sem levar em conta o ambiente em que trabalhou e viveu, poderia distorcer o significado no desenvolvimento da Física. Diante disso, nesta seção, discorreremos um pouco mais sobre o contexto social e científico em que Joule viveu.

Segundo Cardwell (1989), o pai de Joule mudou-se da região central de Manchester para uma localidade mais agradável, talvez por causa da saúde de Joule. Devido a problemas de saúde, sua educação foi lenta, entre os cinco e doze anos de idade. Ele tinha uma fraqueza espinhal, deixando-o corcunda, embora pelas fotos tiradas, em sua fase adulta, não era uma deformidade visível. Apesar destes problemas, Joule teve uma juventude normal e saudável. Embora, estivesse sob tratamento até os 20 anos de idade, era um homem modesto e tímido; tal personalidade poderia estar relacionada aos problemas de saúde que acometeu Joule durante sua vida.

Joule e seu irmão Benjamin não foram enviados para a escola; em vez disso, foram educados em casa, por um tutor chamado Porter; nesta mesma época, Joule e seu irmão iam às tardes de sábado ver os primeiros trens rodando de Liverpool a Manchester. Segundo Cardwell (1989), esta experiência marcou a memória e, possivelmente influenciou os pensamentos futuros de Joule. A rápida propagação da rede ferroviária, a partir de 1830, trouxe o poder, a eficácia e o modo de funcionamento da máquina a vapor, que atraíram a atenção da sociedade na época; os irmãos Joule foram testemunhas do desenvolvimento tecnológico de Manchester. O velho motor pesado da cervejaria poderia ser substituído, enquanto as locomotivas modernas brilhavam como se fosse algo novo.

Esse processo de iniciação de Joule no mundo da Ciência e Tecnologia em uma leitura a partir da perspectiva de Fleck (2010), diz que o complexo processo de formação intelectual depende da vida social do sujeito e o futuro nunca estará totalmente livre do passado. Em outros termos, a constituição da individualidade do sujeito do conhecimento tem, também, componentes relacionadas às interações socioculturais, que fazem mediações na sua convivência, por exemplo, com fenômenos da natureza bruta e transformada.

Em dezembro de 1832, os irmãos Joule tiveram um novo tutor, Frederick Tappenden e, logo em seguida, foram estudar Química sob a orientação de Dalton, que pertencia a Sociedade Literária e Filosófica de Manchester. Dalton exigiu que os estudos fossem baseados em Aritmética e Geometria, começando pelo livro 1 de Euclides. Eles acharam isto desencorajador, mas Dalton foi um professor motivador e pertencia à classe dos geômetras de Lancashire. Naquela época, o entusiasmo para o estudo de problemas geométricos era grande. No início de 1718, uma sociedade matemática tinha sido criada em Manchester, e antes do final do sé- 
culo, havia outra muito ativa, em Oldham. Na verdade, o interesse por Geometria transcendia níveis de classe, pois atingia até as classes operárias (CARDWELL, 1989).

Dalton insistiu sobre os estudos preliminares geométricos que, na época, eram prioridade, antes mesmo da mecânica newtoniana. Era algo que fazia parte da cultura dos geômetras de Lancashire. Segundo Cardwell (1989), qualquer que tenha sido o gosto de Joule pela Geometria e, independentemente do efeito final, não há dúvida de que Dalton fortemente o influenciou na sua aceitação de conceitos chaves e, finalmente, no seu empenho pessoal para a ciência. Além dos estudos de Geometria, Dalton também ensinou Química, principalmente no seu livro Novo Sistema de Filosofia Química.

O uso da Matemática influenciou o trabalho futuro de Joule, ao contrário de outros físicos experimentais, como Faraday (CARDWELL, 1989). Mesmo que nesta época, Joule tenha somente interagido com Dalton, para se apropriar de conhecimentos e práticas da Química e da Geometria, podemos considerar que eles estariam formando um coletivo. Um coletivo de pensamento (CP) existe sempre que duas ou mais pessoas trocam ideias. "É um mau observador, quem não percebe que uma conversa estimulante entre as pessoas pode produzir um estado, no qual cada pessoa expressa pensamentos, que talvez não expressasse sozinha ou em outra companhia" (FLECK 1986, p. 90).

Segundo Steffens (1979), Dalton serviu de inspiração para Joule, principalmente sobre a forma de proceder no processo de experimentação. Ele insistia sobre o cuidado que se deveria ter na experimentação, a sua habilidade na construção de aparelhos simples e sua ênfase sobre os resultados quantitativos são características que se tornaram importantes nos trabalhos posteriores de Joule. O próprio Joule afirmou que Dalton o inspirou a realizar suas próprias pesquisas, a fim de obter novos conhecimentos.

Após Dalton ter sofrido um derrame, as relações entre os dois mantiveram-se até a morte de Dalton. Os irmãos Joule visitaram Dalton, quando estava doente e, ocasionalmente, em algumas tardes foram convidados a tomar chá. Dalton parece ter seguido com interesse os progressos do ex-aluno. Em uma reunião da Sociedade Literária e Filosófica de Manchester, em novembro de 1841, Joule leu um artigo sobre a Origem elétrica do Calor de Combustão e Dalton estava presente. Após a leitura deste artigo, que foi publicado na Revista Filosófica, Joule foi eleito membro da Sociedade Literária e Filosófica de Manchester, em 25 de Janeiro de 1842. Neste caso, parece provável que Dalton influenciou a eleição de Joule para a sociedade, já que ele próprio a presidiu antes de sua doença (STEFFENS, 1979).

Os interesses científicos de Joule desenvolveram-se durante e depois dos anos de tutelagem. Inicialmente, parece que os experimentos elétricos foram seu campo de estudo preferido. Os experimentos de Joule começaram em casa, onde testava os efeitos de choques elétricos nas empregadas domésticas; conduzia pipas elétricas e deu em si mesmo e em seus amigos, choques por meio das garrafas de Leyden e máquinas elétricas primitivas (CARDWELL, 1989). 


\section{III.1 Alguns elementos culturais do trabalho de Joule: a influência da indústria cervejei-} ra

Segundo Rosenfeld (1952), o acúmulo da riqueza nos últimos anos do século 18, criou uma demanda para aumentar a produção; em consequência, começa o processo de substituição de ferramentas manuais por máquinas e depois o fornecimento de energia para alimentar as mesmas. Estas mudanças nos métodos de produção provocaram uma revolução no conjunto social da sociedade, que passou a ser centrada mais na produção do que no comércio. $\mathrm{O}$ interesse da comunidade científica, naturalmente, foi orientado para a utilização das forças da natureza, na obtenção de energia mecânica.

Exatamente nesse tipo de comunidade, que Joule cresceu. Filho de um rico fabricante de cerveja foi capaz de iniciar as investigações, inspirado por sua curiosidade científica. Mas, por outro lado, o pano de fundo desta curiosidade foi determinado pelos interesses das pessoas, no meio em que ele foi criado, conduzido a estudar os aspectos dos fenômenos, que podiam lançar luz sobre as possibilidades de transformação de diversos agentes naturais em energia mecânica (ROSENFELD, 1952).

Nessa direção, estudar os elementos culturais que o influenciaram pôde possibilitar um melhor entendimento do seu trabalho técnico científico. Assim, além das influências apresentadas na seção anterior, destacaremos, neste artigo, alguns elementos culturais que faziam parte da indústria cervejeira. Além disso, queremos destacar a importância de algumas dimensões tácitas ${ }^{4}$ (que também é uma preconcepção do conhecimento científico) do saber experimental, desenvolvido na cervejaria em que James Prescott Joule trabalhou (QUEIRÓS, 2012).

Sibum e Morel (1998) identificaram conhecimentos tácitos profundos em termometria, que influenciaram no trabalho experimental de James Prescott Joule, sobretudo na sua famosa experiência do Equivalente Mecânico do Calor. Nossa proposta é explicitar a história dos saberes tácitos da indústria cervejeira, fazendo um paralelo com o trabalho experimental de James Prescott Joule.

Na primeira parte do artigo, os autores descrevem a cultura da cervejaria, no início do século XIX, cujos saberes locais eram fortemente regidos por uma ordem sensorial complexa em que o toque, o olfato e o gosto tinham a mesma importância que o olhar e a audição. O fato é que nas práticas desta comunidade, habilidades termométricas eram largamente difundidas.

Assim, nos próximos parágrafos até o fim dessa seção, onde não houver citação de referenciais, a descrição textual está baseada no artigo: Les gestes de la mesure: Joule, les pratiques de la brasserie et la science de Otto Sibum and Ginette Morel (1998, p. 745-774).

\footnotetext{
${ }^{4}$ O conhecimento tácito é complexo, desenvolvido e interiorizado durante longos períodos de tempo, sendo quase impossível reproduzi-lo num documento ou numa base de dados. É precisamente este tipo de conhecimento que medeia o dia-a-dia dos indivíduos, contendo uma aprendizagem tão pessoal que as suas regras podem ser dificilmente separáveis da forma como cada indivíduo age. Por esta razão, sendo experiencial, pessoal, específico e ligado a um dado contexto, o conhecimento tácito é, pois, mais difícil de formalizar, comunicar e partilhar com os outros (POLANYI, 1966).
} 
O mundo da cervejaria, no começo da época vitoriana, era considerado, por uma grande parte, uma cultura oral, onde os saberes eram compartilhados pelo exemplo e pela prática. A escrita não representava quase nenhum papel, já que a maioria dos cervejeiros e produtores de malte não sabia ler e nem escrever. Durante o processo de preparação da cerveja, o cervejeiro mastigava um pouco de malte com a finalidade de estabelecer a cor, a quantidade de calor que poderia receber em um recipiente resistente a pressões elevadas; estimava, também, a quantidade de calor que o malte necessitaria no grande recipiente que era determinado, mergulhando a mão no suco vegetal, preparado para a fermentação alcoólica.

Para os cervejeiros e malteiros, o calor era a preocupação principal e na cervejaria, buscavam saber sobre a natureza e formas de manipulação do calor. A visão de calor era substancialista, pois acreditavam que todos os corpos eram armazenados por ele. Este calor contido nos corpos era chamado de latente que ficava inativo ou ativo. Tinham a crença em um Criador e sabiam que todas as coisas eram incertas, transmutáveis e efêmeras e que o autor onipotente de todas as coisas criadas tinha promulgado uma lei universal que se aplicava ao calor. Para eles, um corpo com mais calor transfere calor para outro corpo com menos calor e, a partir deste princípio, é possível transformar um corpo sólido em líquido e um líquido em vapor.

Esses saberes tácitos da cervejaria eram difíceis de serem comunicados por escrito; então, para expressar melhor esta cultura da cervejaria, de sua maneira de agir e aprender, os autores chamavam estes conhecimentos de saber gestual. Este saber envolvia práticas manuais e mentais e somente alguns autores de obras sobre cervejaria eram obrigados a fazer a distinção para explicar ao leitor certas operações complexas. O saber gestual era flexível, exigia atitude e era requisitado para as medidas de calor que ocorria mais pelo afinamento sensorial da mão, alcançando a percepção do meio. O discípulo só aprendia imitando os gestos do mestre, mergulhando a mão na mesma bacia, no mesmo recipiente.

O emprego de instrumentos como o termômetro, nas mãos de um experimentador, depende das técnicas utilizadas na atividade corporal, privilegiada pelo indivíduo que pertence a uma comunidade, onde aproveita de um estatuto particular. A maneira como os cervejeiros mediam o calor era, em parte, uma técnica manual específica com uma série de atos montados pelo indivíduo, não simplesmente por eles mesmos, mas por toda sua educação, por toda a sociedade de que faz parte, no lugar onde ocupa. O saber gestual do cervejeiro foi, então, fortemente determinado por sua aprendizagem de um controle das ações, de acordo com as práticas educativas tradicionais da comunidade.

Durante os anos de 1830, a indústria da cervejaria passou por mudanças radicais no universo sensorial. Foi publicada uma enciclopédia sobre a cervejaria por George Adolphus 
Wigney 5 , para criar uma comunidade de cervejeiros científicos, capazes de satisfazer as novas exigências econômicas.

Wigney via, nas velhas cervejarias, a produção de fatos relativos e não fatos com uma tendência mais geral, pois os saberes ficavam reduzidos somente a um local específico, sendo difícil transferir para outro. A atividade prática do cervejeiro e o seu saber gestual necessário às medidas do calor eram estruturados pela arquitetura do prédio, a qualidade, a altura dos utensílios e a disposição dos equipamentos técnicos que caracterizavam o lugar.

Enfim, Wigney tentou sistematizar as bases conceituais desta nova fase da indústria cervejeira, mas tinha a consciência de que o saber gestual do cervejeiro era difícil de registrar por escrito; assim, ele traduziu na linguagem da química, não somente sua própria experiência profissional, mas também um texto histórico de comunicações orais com os jargões dos cervejeiros. Ele tinha a consciência de que, mesmo sistematizando a prática da cervejaria, dentro dos padrões da racionalidade científica, podia fornecer informações úteis, no entanto, sem transformar o leitor em um cervejeiro experimentador. Portanto, o objetivo principal de Wigney era sistematizar o conhecimento da cervejaria com a finalidade de atender a expansão industrial, pois uma prática limitada somente a discípulo e mestre ficava restrita somente a um lugar; a meta era que estas técnicas se expandissem para o maior número de indústrias possíveis.

Para a administração britânica, a diversidade de experiências dos cervejeiros e malteiros, com métodos de medidas, variando de acordo com os lugares, dificultava a evolução econômica da sociedade vitoriana. Diante disso, em paralelo ao processo de catalogação feito por Wigney, começou-se a exigir uma precisão por parte dos instrumentos de medida. Tal exigência ocorreu devido à demanda dos produtores de cerveja que, buscando uma maior exatidão e eficácia da cervejaria, conquistaram melhores e maiores mercados. Por outro lado, a administração pública inglesa buscava, de forma mais precisa, cobrar os impostos.

$\mathrm{O}$ fato é que a exigência da administração pública, pela necessidade de medidas cada vez mais confiáveis, para impor seus impostos aos comerciantes e mercadores, provocou uma discórdia entre o governo, os malteiros e cervejeiros, na maneira de trabalhar, pois, se exigia mais economia nos gastos no processo de preparação da cerveja, o que consequentemente, fez com que os cervejeiros mudassem algumas de suas técnicas como, por exemplo, o tempo de duração do malte de $72 \mathrm{~h}$ passou a ser de $50 \mathrm{~h}$, porque gerava menos custos (SIBUM; MOREL 1998, p.752).

Um ponto importante deste desentendimento entre governo e fabricantes de cerveja foi em 1847, devido ao excessivo aumento de impostos aos produtores de cerveja e malte. As medidas eram impostas de tal maneira que oprimiram os fabricantes, subindo os preços dos produtos e abaixando a qualidade da cerveja. Isto teve como consequência uma diminuição do

\footnotetext{
5 Não conseguimos encontrar o seu ano de nascimento e falecimento. Ele escreveu várias obras com o objetivo de sistematizar o conhecimento sobre a produção de cerveja, como exemplo, publicou, em 1835, a famosa obra: Um tratado teórico e prático sobre maltagem e fabricação da cerveja.
} 
consumo de cerveja, favorecendo o consumo pela população de chá e outras bebidas alcoólicas.

Esses problemas econômicos fizeram com que muitos cervejeiros, que estavam acostumados com os saberes gestuais, fossem se adaptando às técnicas dos cervejeiros científicos, como as propostas de Wigney de recorrer a técnicas quantificadoras. Desta forma, desde a virada do século, hidrômetros e termômetros eram companheiros inseparáveis dos homens da cervejaria.

A utilização do hidrômetro serviu de auxílio para determinar a titulação da cerveja e de outras bebidas alcoólicas; no entanto, antes de ser utilizado pela indústria cervejeira foi utilizado pela Alfândega, órgão da administração pública, para subsidiar as práticas de normatização de cobrança de impostos, utilizados, principalmente, no decorrer do ano de 1837.

O termômetro era o instrumento que fazia uma dupla com o hidrômetro na indústria cervejeira. $\mathrm{O}$ termômetro era utilizado para determinar os calores padrões que permitiriam aos cervejeiros e aos fiscais de impostos determinarem, de forma mais precisa, a titulação dos líquidos. No entanto, concluíram que não existe um calor ideal de preparação da cerveja, mas que é variável, ou seja, nem sempre a mesma quantidade de calor convém à cura e as duas preparações sucessivas de cerveja do mesmo malte. Medir boas temperaturas de preparação da cerveja era uma operação difícil, mas um dos grandes segredos da profissão, que a maioria não revelava. Wigney esperava reunir dados suficientes com o objetivo de determinar a boa temperatura da cerveja, de acordo com a produção e a época do ano.

Wigney tinha a convicção de que os cervejeiros teriam que mudar os seus saberes, pois a cerveja fornecida ao público era a que tinha de 2 a 3 anos de idade e o público exigia outro tipo de cerveja com mais qualidade, o que definia a produção anual do cervejeiro. Diante desta demanda econômica, termômetros decimais tornaram-se técnicas práticas e teóricas indispensáveis aos cervejeiros, ou seja, a construção de termômetros que exprimissem as suas medidas com exatidão tornou-se uma necessidade. Desta forma, o próprio governo e a indústria cervejeira, com seus interesses econômicos, investiram, fortemente, na construção de instrumentos de precisão. Isto possibilitou a interação dos laboratórios responsáveis pela construção dos instrumentos com as Universidades.

A exigência do desenvolvimento das técnicas de precisão, portanto, necessita da aquisição de um novo rigor gestual que não obedecia, necessariamente, aos modelos de atividades corporais habituais aos filósofos naturais. Para Wigney a nova forma da indústria cervejeira contribuiu para criar novas hierarquias entre o espírito e o corpo.

Alguns dos conhecimentos tácitos da cervejaria discutidos e seu processo de cientifização, por meio da sistematização de Wigney e das pressões econômicas, exemplificam muito bem as relações entre os saberes populares e científicos estabelecidas por Fleck (2010, p. 165):

[...] Quando um economista fala em organismo econômico, ou filósofo em substância, ou um biólogo no estado de células todos utilizam em sua própria especialidade 
conceitos oriundos do repertório popular do saber. Ë em torno destes conceitos que constroem as ciências especializadas, e mais adiante, teremos a oportunidade de constatar permanentemente, nas profundezas dessas ciências, elementos do saber popular de outras áreas. Esses elementos foram muitas vezes decisivos para o conteúdo do saber especializado, predeterminando seu desenvolvimento por décadas.

Nesse sentido, podemos dizer que muitos desses 'saberes tácitos' fazem parte do cerne de muitas técnicas da indústria no mundo atual. Cabe ressaltar que Fleck dialetiza estas relações dos saberes populares e científicos, um interagindo com o outro por meio dos círculos esotérico (especialistas) e exotérico (coletivo de leigos), ou seja, sob determinadas condições, o conhecimento científico pode chegar até às massas populares e aperfeiçoar, ou até mesmo, substituir o saber popular (QUEIRÓS, 2012).

Assim, acreditamos que a apresentação da cultura da cervejaria, o processo de transformação dos conhecimentos tácitos passando pela influência dos fatores econômicos, nos ajudam a compreender as influências lógicas, culturais e econômicas no trabalho de Joule. A cervejaria do pai, o senhor Benjamim Joule, por volta de 1830, produzia em torno de 10.000 a 20.000 barris por ano, o que possibilitou fornecer o capital necessário para proporcionar a seus filhos uma boa educação. O irmão resolveu seguir uma carreira na música, enquanto Joule seguiu tanto o caminho da ciência, quanto o trabalho na cervejaria do pai (CARDWELL, 1989).

Assim, desde os 16 anos de idade, Joule trabalhou com o pai na cervejaria diuturnamente, durante 20 anos; usava as dependências da cervejaria para executar os seus projetos científicos. Ele realizou diversas experiências com o objetivo de aperfeiçoar as técnicas da cervejaria, sempre pensando em compreender a natureza de como economizar calor, ou seja, menos gastos nos processos de conversão. Os instrumentos de precisão eram, como afirmamos anteriormente, os principais recursos utilizados pelos técnicos e cientistas, incluindo a figura de Joule; era uma prática comum utilizar o termômetro para medir a temperatura de preparação da cerveja (CARDWELL, 1989).

Nesse contexto, uma das questões mais solicitadas foi o aperfeiçoamento dos instrumentos de medida; a prioridade principal era a construção de termômetros com grande exatidão e sensibilidade. Na Sociedade Literária e Filosófica de Manchester, havia um homem que poderia construir estes instrumentos: John Benjamin Dancer (1812-1887), que veio de Liverpool para Manchester, com o objetivo de abrir uma loja e uma fábrica de instrumentos. Dancer era mais que um técnico, era um filósofo experimental, químico, industrial e professor de Química nesta instituição real de Manchester, que se tornou famoso por suas microfotografias.

A construção e o teste de termômetros, com um modelo confiável, era um trabalho de sábios. Os artistas que produziam vidros tradicionais não eram mais capazes de satisfazer as normas de precisão requisitadas pela pesquisa científica; termômetros construídos pelo mesmo fabricante podiam diferenciar mais de um grau Fahrenheit. Joule passava longas horas 
no atelier de Dancer, estudando normas de graduação, instrumentos estrangeiros e colocando em prática a sua técnica e verificando uma medida pela comparação com um modelo de termômetro. Um dos instrumentos de precisão mais importante, que Dancer chamou de microscópio móvel, permitia construir um termômetro extremamente sensível, o mais preciso da época, que permitia verificar medida e graduar termômetros (CARDWELL, 1989).

$\mathrm{Na}$ cervejaria, Joule adquiriu o saber gestual necessário para efetuar medidas de temperatura, também complexas. Este saber gestual aprendido na cultura dos cervejeiros, talvez explique o porquê não se encontra em suas notas de laboratório, onde ele instalava o termômetro para medir a temperatura do ar, nem sobre a maneira de medir a temperatura da água nos recipientes. Joule interiorizou o ritmo de trabalho dos cervejeiros, pois o seu repertório de medidas emanava de sua prática experimental na cervejaria.

Para termos ideia de como a cervejaria influenciou o trabalho experimental de Joule, parte do aparato do experimento do Equivalente Mecânico do Calor, ou seja, da agitação da água através das pás, refletia a sua prática de cervejeiro; as rodas de metal e o recipiente de água foram uma versão reduzida de um recipiente utilizado na cervejaria. No entanto, a inspiração inicial para o ensaio foi uma adaptação do aparato utilizado por George Rennie (17911866), em sua experiência sobre o atrito da água. O objetivo dos dois experimentos foi, porém, muito diferente. Rennie estava interessado apenas na fricção de fluidos em superfícies diversas e as palhetas em seus aparatos foram desenhadas para testar a resistência da água contra elas, bem como a quantidade de atrito experimentado pela água contra os lados do recipiente; Joule modificou o aparato para que o movimento de agitação da água, através das pás, impedisse o movimento de translação da água. A força mecânica gasta pela roda de bronze, em girar a água no interior do recipiente, foi medida por meio do arranjo de peso e polia utilizados em suas experiências anteriores, sobre um circuito eletromagnético voltaico (QUEIRÓS, 2012).

Cabe ressaltar que, detalhes de como ele instalava o termômetro para medir a temperatura do ar e a maneira de aferir a temperatura da água no recipiente de metal não se encontram em suas notas e relatórios de laboratório, pois, estas questões estão diretamente ligadas aos saberes tácitos adquiridos na cultura dos cervejeiros. Neste sentido, a adega da cervejaria foi utilizada como local para sua experiência do Equivalente Mecânico do Calor, pois reunia as condições razoáveis para a realização de seu ensaio, com qualidade (QUEIRÓS, 2012).

Assim, o ambiente cultural da cervejaria ofereceu um leque de modelos para Joule, que influenciou diretamente as suas pesquisas sobre o calor, ou seja, a forma de trabalhar dos velhos cervejeiros, a busca da exatidão que significava para a cervejaria: qualidade da atenção e da execução. O trabalho de Joule ilustra um método artesanal e, graças ao saber gestual de Dancer, na fabricação de instrumentos de precisão, ele se sentiu mais seguro na própria execução das medidas de seus instrumentos. Mesmo assim, ele testou a exatidão do seu termômetro com os melhores termômetros da época, como os termômetros de Thomas Graham (18051869), professor de Química da Universidade de Londres, especialista em análises químicas e 
de Lyon Playfair (1818-1898), colega de trabalho. Desta forma, Joule criou um pequeno grupo, em que um compreendia o trabalho do outro e transformou a cervejaria em um lugar de produção do saber.

\section{III.2 Elementos teóricos que influenciaram a visão técnico-científica de Joule: os aspec- tos da instrumentação, exatidão e precisão}

Segundo Rosenfeld (1952), a biografia de Joule escrita por Reynolds defende que não teve influências teóricas preconcebidas. Para o autor, Joule chega as suas conclusões, apenas baseado nos resultados dos experimentos, ou seja, uma visão empirista-indutivista do conhecimento científico.

Para Rosenfeld, a visão empirista-indutivista do trabalho de Joule é equivocada e superficial, pois o seu trabalho mostra o contrário. No início dos seus trabalhos, quando descreve suas primeiras experiências sobre o calor produzido pela passagem de corrente através de um condutor (Efeito Joule), demonstra que já estava preocupado com a ideia de equivalência. Quando explicita a verificação por novas medições, a afirmação geralmente aceita que o calor produzido pela passagem da corrente é exatamente proporcional à resistência; a sua preocupação é saber "se a resistência à condução é a única causa dos efeitos do aquecimento". Quando usa nesta sentença a palavra "única" é para indicar uma ideia preconcebida em sua mente, da equivalência entre os fenômenos da produção de calor e da passagem da corrente através da resistência:

É bem conhecido que a facilidade com que um fio metálico é aquecido pela corrente voltaica é inversamente proporcional à sua condução de energia, e acredita-se geralmente que essa proporção é exata. No entanto, gostaria de conhecer o fato para minha própria satisfação e, especialmente, como era de extrema importância saber se a resistência à condução é a única causa dos efeitos do aquecimento. O detalhe, portanto, de algumas experiências de confirmação da lei, para além das já indicadas nas páginas de ciência, não será, espero eu, considerado supérfluo (JOULE, 1841, p. 60).

O interesse de Joule no calor produzido pela condução de eletricidade não era original; houve uma série de investigações antes de 1840, e Joule parece ter tido conhecimento destas pesquisas. Em 1821, Sir Humpry Davy tinha chamado a atenção para o calor produzido por um fio, na condução de eletricidade em suas pesquisas sobre os fenômenos magnéticos produzidos pela eletricidade (STEFFENS, 1979, p. 25).

Pesquisas extensas sobre a relação entre a condução de eletricidade e a produção de calor foram realizadas por William Snow Harris (1791-1867) e Joule o havia estudado; seu próprio trabalho foi uma ampliação do trabalho de Harris com maior atenção dada as experiências e uma tentativa de maior precisão. Joule fez uma suposição, que não aparece na obra de Harris, de que a eletricidade é a causa do calor desenvolvido. Esta busca de maior precisão 
e sua suposição constitui-se em uma leitura a partir de Fleck (2010) de elementos pré-teóricos do trabalho sobre o efeito Joule.

Joule decidiu testar o conteúdo experimental do trabalho de Harris por acreditar na hipótese de que existe um organismo invisível no mundo natural, designado pelo termo eletricidade, que pode ser inferido, a partir do contato de corpos desiguais, por fricção e mudanças de temperatura. Ensaios foram feitos com resultados precisos de mesmo caráter; todos conspiraram para o fato de que, quando uma dada quantidade de eletricidade voltaica é passada através de um condutor metálico, durante um determinado período de tempo, a quantidade de calor desenvolvida por ele é sempre proporcional à sua resistência ${ }^{6}$, qualquer que seja o seu comprimento, espessura, forma ou espécie de condutor metálico (JOULE, 1841, p. 64).

Joule também concluiu que: "Quando uma corrente elétrica voltaica é propagada ao longo de um condutor metálico, o calor desenvolvido num dado tempo é proporcional à resistência do condutor multiplicada pelo quadrado da intensidade elétrica" (JOULE, 1841, p.65); o que contradizia o resultado de Harris em seu artigo de 1834, o poder de aquecimento da eletricidade era diretamente proporcional à corrente. Depois de confirmar a lei ri² para condutores metálicos, ele mostrou a extensão de sua lei para condutores líquidos e gasosos.

Assim, para construir uma explicação para o fenômeno "efeito Joule", partiu de hipóteses e estudos de outros pesquisadores como os de William Snow Harris, mostrando suas contradições e chegando a uma explicação mais precisa do fenômeno, como conhecemos atualmente. Nesta direção, Rosenfeld (1952) concluiu que Joule foi inspirado, desde o início, por suposições teóricas: a ideia da natureza dinâmica do calor e, talvez, inicialmente, não muito articulada com a ideia de uma equivalência entre calor e outros agentes físicos. As experiências realizadas sobre a relação entre calor e eletricidade foram feitas com o propósito de testar as ideias, de que não é a simples busca de confirmação; mas, no caso das experiências realizadas sobre o calor produzido pela passagem de corrente elétrica em um condutor, cujo objetivo é entender as causas do efeito de aquecimento.

No entanto, Rosenfeld não aborda, de maneira mais aprofundada, outros elementos teóricos importantes, como o papel da exatidão e a instrumentação no trabalho experimental de Joule que são características da ciência moderna. Os seus trabalhos estavam diretamente relacionados à construção dos melhores instrumentos e a obtenção de medidas precisas. Nesta direção, entendemos ser rico fazer uma análise do trabalho de Joule, a partir de ponderações com o trabalho de Koyré, ou seja, procuraremos fundamentar estes elementos por meio dos estudos sobre Galileu e Platão por meio do livro: Galileu e Platão, Editora Gradiva, mais especificamente o capítulo: "Do Mundo do "mais ou menos" ao Universo da Precisão.

Koyré faz um estudo explicitando as mudanças de qualidade na relação techneepisteme, no advento da ciência moderna, conforme analisa Delizoicov (1996). Assim, explora conceitos centrais de precisão e exatidão, valores originados e criados a partir de problemas

\footnotetext{
6 Para época, Harris e outros chegaram nesta lei de forma muito satisfatória, usando a eletricidade comum.
} 
relativos à concepção teórica de medida e da matematização da natureza. Tais valores são anteriores a própria execução da tecnologia:

Não é do desenvolvimento espontâneo das artes industriais pelo que elas exercem, mas sim da conversão da teoria em prática, que Descartes espera os progressos que tornarão o homem 'senhor e dono da natureza' [...] (e) da possibilidade de fazer a teoria penetrar a ação, isto é, a possibilidade da conversão da inteligência teórica em real, da possibilidade, a um tempo, de uma tecnologia e de uma física. [...] Creio [...] que a história, ou, pelo menos, a pré-historia da revolução técnica dos séculos XVII e XVIII confirma a concepção cartesiana: é por uma conversão da episteme na techne que a máquina eotécnica se transforma na máquina moderna (paleotécnica); porque esta conversão, por outras palavras, a tecnologia nascente, que da à segunda o que forma seu próprio caráter e a distingue radicalmente da primeira, e que mais não é do que a precisão (KOYRÉ, s.d., p. 66-67).

Koyré, ao fazer o estudo sobre os instrumentos de medida, declara que eles não são apenas um prolongamento dos sentidos, mas uma concepção teórica da mente humana:

[...] Um utensílio, isto é, qualquer coisa que, tal como já tinha visto, e muito bem, o pensamento antigo, prolonga e reforça a ação dos nossos membros, dos nossos órgãos dos sentidos; qualquer coisa que pertence ao mundo do senso comum. E que nunca pode levar-nos a ultrapassá-lo; quando, pelo contrário, a própria função do instrumento não é um prolongamento dos sentidos, mas, na acepção mais forte e mais literal do termo, uma encarnação do espírito e uma materialização do pensamento (KOYRÉ, s. d., p. 75).

Muitos instrumentos utilizados por Joule eram produzidos por ele mesmo, como o termômetro e o galvanômetro, que procurava aperfeiçoá-los a fim de obter resultados os mais precisos possíveis. Para Koyré, a ideia de se criar e aperfeiçoar os instrumentos está diretamente relacionada à exatidão e à precisão, que são alguns dos elementos teóricos que motivaram a criação de tais instrumentos e cita o exemplo de Galileu, no aperfeiçoamento da luneta:

[...] Galileu, logo que teve a notícia da luneta de aproximação holandesa, elaborou sua teoria. E foi a partir desta teoria, sem dúvida insuficiente, mas teoria apesar de tudo, que, levando cada vez mais longe a precisão e o poder dos seus vidros, construiu a série das suas perspicilles, que lhe abriram aos olhos a imensidade do céu. [...] Não vai mais longe, não pretende ir mais além - e não foi por acaso que nem os inventores, nem os utentes da luneta holandesa se serviram dela para observar o céu. Pelo contrário, foi para responder a necessidades puramente teóricas, para atingir o que não cai na alçada dos nossos sentidos, para ver o que ninguém jamais viu que Galileu construiu os seus instrumentos: o telescópio e depois o microscópio. [...] é necessário construir máquinas cada vez mais precisas, máquinas matemáticas, que, tal como os próprios instrumentos, pressupõem a substituição, no espírito dos seus inventores, do universo do aproximadamente pelo universo da precisão. [...] (KOYRÉ, p. 75-82). 
Para Koyré, existe uma relação de mão dupla entre os elementos teóricos e práticos, já que o teórico pode possibilitar a construção de um objeto prático, assim como um objeto prático (que anteriormente foi formulado por uma concepção teórica) pode inspirar um pensamento teórico:

[...] O relógio de precisão, o relógio cronométrico, tem uma origem completamente diferente. Não é, de modo algum, uma promoção do relógio prático. Ë um instrumento, quer dizer, uma criação do pensamento científico. Ë um instrumento, quer dizer uma criação, ou, melhor ainda, a realização consciente de uma teoria. $\ddot{E}$ certo que, uma vez realizado, um objeto teórico se pode tornar um objeto prático de uso corrente e cotidiano. Ë certo também que considerações práticas - no caso que nos interessa, o problema da determinação das longitudes, que a extensão da navegação tornava cada vez mais urgente-podem inspirar o pensamento teórico. Mas não é a utilização de um objeto que lhe determina a natureza: é a estrutura; um cronômetro permanece um cronômetro mesmo se forem marinheiros a utilizá-lo. Isto explica-nos por que razão não é aos relojoeiros, mas aos sábios, não a Jost Burgi e a Isaak Thuret, mas a Galileu e a Huygens (e a Robert Hooke também), que remontam as grandes invenções decisivas a que devemos o relógio do pêndulo e o relógio de espiral reguladora (KOYRÉ, p. 82-83).

Essa relação de mão dupla é constante no trabalho de Joule, é como se fosse um Galileu na construção de termômetros e galvanômetros. Joule antes de realizar os seus experimentos, fazia todo um planejamento com a finalidade de construir e aperfeiçoar os instrumentos para alcançar medidas cada vez mais precisas e exatas, principalmente, no estudo do Equivalente Mecânico do Calor. Com relação ao papel da exatidão, Koyré assim explica:

[...] Se os quadrantes solares e os relógios de foliot eram, no século XVII, largamente suficientes para o grande público, já para os sábios não o eram. Era lhes necessário descobrir uma medida exata. Ora "os processos empíricos eram impotentes para esta descoberta e apenas os teóricos, aqueles que precisamente nesta época elaboravam as teorias e estabeleciam as leis da mecânica racional, eram capazes de fazer. Portanto, os físicos, os mecânicos, os astrônomos, sobretudo os maiores dentre eles, preocuparam-se com o problema a resolver pela simples razão de serem os primeiros interessados" (KOYRÉ, s.d., p. 84).

Dessa forma, Koyré (p.89) conclui que a busca da exatidão e precisão são elementos teóricos. Para ele, a história da cronometria é um marco do nascimento tecnológico que leva a realidade técnica a um plano superior. Esta euforia técnica se deve à grande motivação da busca pela exatidão pelos técnicos da época e Joule é um desses personagens, que deixou a sua marca naquele período. Assim, de acordo com Koyré, o instrumento de precisão é decisivo na realidade das medições do aproximadamente; é, na construção dos instrumentos, que se consagra o pensamento tecnológico, que se constroem máquinas precisas e a constante busca da indústria por máquinas cada vez mais precisas. Em suma, para o autor, é pela supremacia 
da teoria sobre a prática que poderíamos caracterizar a técnica da segunda revolução industrial, iniciada na segunda metade do século XIX.

A explicação das motivações de Joule está contida no seu ambiente social, da segunda metade do século XIX (ROSENFELD, 1952). Tal período teve um rápido crescimento e concentração do processo de produção, exigindo um aumento enorme no desenvolvimento das fontes de força motriz, na utilização de metais nobres, na construção de pontes e máquinas poderosas. Cientistas interessados em tais temas foram influenciados pelo seu íntimo contato com a matéria em seus aspectos mais sólidos. Isto contribuiu para Joule e seus seguidores, mesmo que inconscientemente, seguirem fortemente uma visão mecanicista do mundo material.

\section{Considerações finais}

Essa análise dos elementos teóricos e socioculturais do trabalho de Joule possibilita contribuições, que consideramos importantes, para o ensino de Física. A partir do estudo, esperamos que professores de diferentes níveis e estudantes da escola básica compreendam a natureza do conhecimento científico, no que diz respeito à relação de mão dupla entre os elementos teóricos e socioculturais, que influenciaram o trabalho técnico-científico de Joule; que, em consequência, é um exemplo para mostrar que a Ciência não é uma atividade puramente empirista e indutivista e nem descontextualizada e neutra.

Do ponto de vista dos elementos teóricos que influenciaram Joule, Dalton serviu de inspiração para Joule, principalmente, sobre a forma de proceder no processo de experimentação. Ele insistia sobre o cuidado que se deveria ter na experimentação, a sua habilidade na construção de aparelhos simples e sua ênfase sobre os resultados quantitativos são características que se tornaram importantes nos trabalhos posteriores de Joule. Ele próprio afirmou que Dalton o inspirou a realizar suas pesquisas, a fim de obter novos conhecimentos.

Nessa direção, antes de realizar os experimentos, Joule já possuía preconcepções teóricas, que contribuíram para uma visão epistemológica diferente do empirismo-indutivismo. Um exemplo dos pressupostos teóricos foi o seu procedimento no estudo do efeito Joule. Como descrevemos aqui, Joule conhecia o trabalho de outros pesquisadores sobre o estudo do efeito do calor produzido pela passagem de corrente elétrica em condutores, como por exemplo, o trabalho sobre o aquecimento de condutores desenvolvido por William Snow Harris. Joule, ampliou e buscou maior precisão do trabalho de Harris.

Isso ocasionou uma mudança na lei que, para Harris, o calor desenvolvido no condutor era diretamente proporcional a corrente elétrica, enquanto Joule mostrou, como conhecemos atualmente, ser diretamente proporcional ao quadrado da corrente. Além disso, Joule fez uma suposição, que não aparece na obra de Harris, de que a eletricidade é a causa do calor desenvolvido. Esta busca de maior precisão e sua suposição constituem-se em elementos préteóricos do trabalho sobre o efeito Joule. Esta análise, de certa forma, contribui para o proces- 
so de formação de professores, para que os mesmos compreendam o complexo processo de construção do conhecimento, ou seja, que a teoria pode preceder a observação.

A busca de exatidão e precisão são outros elementos teóricos que permearam os trabalhos de Joule sobre o Efeito Joule e o Equivalente Mecânico do Calor. Joule recebeu também motivação de Dalton e Faraday. Muitos instrumentos utilizados por Joule eram produzidos por ele mesmo, como o termômetro e o galvanômetro, que procurava aperfeiçoá-los a fim de obter resultados mais precisos possíveis.

Para Koyré, a ideia de se criar e aperfeiçoar instrumentos estão diretamente relacionados à exatidão e à precisão, que são alguns dos elementos teóricos que motivaram a criação de tais instrumentos. No caso, Joule planejou, adaptou e criou os instrumentos necessários para realizar o experimento do "Efeito Joule" e do Equivalente Mecânico do Calor; isto, a partir de uma leitura de Koyré, constitui elementos teóricos que influenciaram o seu trabalho.

Por outro lado, as influências sociais e culturais exploradas no presente estudo, explica que as motivações de Joule estavam contidas no ambiente social vivido por ele, na segunda metade do século XIX. O ambiente industrial de Manchester, a convivência com amigos da família que tinham um conhecimento técnico, a sua infância e adolescência na cervejaria do pai, o patrocínio de industriais e governantes aos inventores foram fatores decisivos e abriram uma disposição mental para a condução da pesquisa de Joule.

Nesse sentido, estudar os elementos culturais que o influenciaram pode possibilitar um melhor entendimento do seu trabalho técnico científico e contribui para o processo formativo de que a ciência está diretamente ligada a fatores sociais e culturais. A apresentação da cultura da cervejaria, o processo de transformação dos conhecimentos tácitos passando pela influência dos fatores econômicos, nos ajudam a compreender as influências lógicas, culturais e econômicas no trabalho de Joule. O saber gestual adquirido por ele, na cultura da cervejaria, necessário para efetuar medidas de temperatura, explica a sua maneira de medir a temperatura da água nos recipientes. Joule interiorizou o ritmo de trabalho dos cervejeiros, pois, o seu repertório de medidas emanava de sua prática experimental na cervejaria.

A cultura da cervejaria influenciou Joule na construção e execução do experimento do Equivalente Mecânico do Calor, ou seja, da agitação da água através das pás, pois, apesar de fazer uma adaptação do experimento de Rennie, as rodas de metal e o recipiente de água constituiram-se em uma versão reduzida de um recipiente utilizado na cervejaria.

Assim, o ambiente cultural da cervejaria ofereceu um leque de modelos para Joule, que o influenciou diretamente em suas pesquisas sobre o calor, ou seja, a forma de trabalhar dos velhos cervejeiros, a busca da exatidão que significava para a cervejaria: qualidade da atenção e da execução. O trabalho de Joule ilustra um método de artesão.

Por fim, entendemos que o trabalho de Joule na cervejaria representou, de uma forma geral, um elo entre os elementos lógicos-formais (a busca pela exatidão e precisão) com elementos sociais e culturais, representado pelo processo de industrialização e problemas sociais dela decorrentes. Na dimensão dos elementos culturais, oriundos da cervejaria, as práticas de 
criação de instrumentos e equipamentos e formas de aferir medidas influenciaram o Trabalho de James Prescott Joule.

Assim, esse estudo histórico-sociocultural que influenciou os trabalhos de Joule, apresentado no presente estudo, pode contribuir para uma prática educacional sobre natureza da ciência, na formação de professores e na educação básica; o que pode proporcionar uma crítica social e cultural da ciência, uma vez que explora os fatores externos que permearam o trabalho de James Prescott Joule.

\section{Referências}

BERNAL, J. D. Ciencia y industria en el siglo XIX. Barcelona: Ediciones Martínez Roca, S.A, 1973. 200 p.

BRASIL. Conselho Nacional de Educação. Parecer CNE/CES no 1304: Diretrizes Nacionais Curriculares para os Cursos de Física. Aprovado em 6 de Nov. 2001, homologada em 04 dez. 2001. Publicado no DOU em 07 dez. 2001.

CARDWELL, D. S. L. James Joule: a biography. Manchester: Manchester University Press, 1989, 333 p.

CASTILHO, N.; CARNEIRO M. H. S; DELIZOICOV, D. O movimento do sangue no corpo humano: do contexto da produção do conhecimento para o seu ensino. Ciência \& Educação, Bauru, v. 10, n. 3, p. 443-460, dez. 2004.

DELIZOICOV, D. O interacionismo na construção dos paradigmas. Pró-Posicões, Campinas, v. 7, n. 1, p. 84-93, mar. 1996.

DELIZOICOV, D. Fleck e a epistemologia pós-empirismo lógico. In: FÁVERO, M. H.; CUNHA, C. da. (Org.). Psicologia do Conhecimento. O diálogo entre as ciências e a cidadania. 1. ed. Brasília: UNESCO, Instituto de Psicologia da UNB, Liber Livro Editora, 2009. Cap. 3, p. 233-258.

EASTWOOD. J. L.; SADLER, T. D.; ZEIDLER, D. L.; AMIRI, L. L.; APPLEBAUM, S. Contextualizing nature of science instruction in socioscientific issues. International Journal of Science Education, v. 34, n. 15, p. 2289-2315, 2012.

FERREIRA, S.; MORAIS, A. M. The nature of science in science curricula: methods and concepts of analysis. International Journal of Science Education, v. 35, n. 16, p. 26702691, 2013.

FLECK, L. La Génesis y el desarrolo de un hecho científico. Madrid: Alianza Editorial, 1986. 
FLECK, L. Gênese e desenvolvimento de um fato científico. Tradução: Georg Otte e Mariana Camilo de Oliveira. Belo Horizonte: Fabrefactum editora, 2010. 205 p.

FONSECA, D. S. Pressão atmosférica e natureza da ciência: uma sequência didática englobando fontes primárias. Caderno Brasileiro de Ensino de Física, v. 34, n. 1, p. 64-108, abr. 2017.

GATTI, S. R. T.; NARDI, R. A História e a Filosofia da Ciência no Ensino de Ciência: A pesquisa e suas contribuições para a prática pedagógica em sala de aula. In: GATTI, S. R. T.; NARDI, R. (Org.) 1. ed. São Paulo: Escrituras, 2016. 240 p.

GIL-PÉREZ D. et al. Para uma imagem não deformada do trabalho científico. Ciência \& Educação, Bauru, v. 7, n. 2, p. 125-153, 2001.

HOBSBAWM, E. J. A era das revoluções. Tradução: Maria Tereza Lopes Teixeira, 22. ed. Rio de janeiro: Paz e Terra, 1977, 464 p.

JOULE, J. P. On the mechanical equivalent of heat. Philosophical Transactions of the Royal Society of London, v. 140, p. 61-82, 1850.

KNIGHT, D. The age of science: the scientific world-view in the nineteenth century. New York: Basil Blackwell, 1986.

KOYRÉ, A. Galileu e Platão. Tradução: Maria Teresa Brito Curado, 1. ed. Lisboa: Gradiva, [s.d]. 89 p.

LEDERMAN, N. G.; ANTINK, A.; BARTOS, S. Nature of science, scientific inquiry, and socio-scientific issues arising from genetics: a pathway to developing a scientifically literate citizenry. Science \& Education, v. 23, p. 285-302, 2014.

MARTINS, A. F. P. Natureza da ciência no ensino de ciências: uma proposta baseada em "temas" e "questões". Caderno Brasileiro de Ensino de Física, v. 32, n. 3, p. 703-737, dez. 2015.

MATTHEWS, M. R. Science teaching: the role of history and philosophy of science. New York: Routledge, 1994.

PARASKEVOPOULOU, E.; KOLIOPOULOS, D. Teaching the nature of science through the millikan-ehrenhaft dispute. Science \& Education, v. 20, p. 943-960, 2011.

QUEIRÓS, W. P. A articulação das culturas humanísticas e científica por meio do estudo histórico sociocultural dos trabalhos de James Prescott Joule: contribuições para a formação de professores universitários em uma perspectiva transformadora. 2012. 355 f. Tese (Doutorado em Educação para a Ciência) - Faculdade de Ciências, Universidade Estadual Paulista (UNESP), Bauru, SP. 
QUEIRÓS, W. P.; NARDI, R.; DELIZOICOV, D. A produção técnico-científica de James Prescott Joule: uma leitura a partir da epistemologia de Ludwik Fleck. Investigações em Ensino de Ciências, Porto Alegre, v. 19, n. 1, p. 99-116, mar. 2014.

ROSENFELD, L. Joule's scientific outlook. Bulletin of the British Society for the History of Science, v. 1, n. 7, p. 169-176, 1952.

SCHEID, N. M. J.; FERRARI, N.; DELIZOICOV, D. A construção coletiva do conhecimento científico sobre a estrutura do DNA. Ciência \& Educação, Bauru, v.11, n. 2, p. 223-233, mai/ago. 2005.

SIBUM, H. O.; MOREL, G. Les gestes de la mesure: Joule, les pratiques de la brasserie et la science. Annales Histoire, Sciences Sociale, ano 53, n. 4/5, p. 745-774, 1998.

SILVA, C. C.; MOURA, B. A. A natureza da ciência por meio do estudo de episódios históricos: o caso da popularização da óptica newtoniana. Revista Brasileira de Ensino de Física, São Paulo, v. 30, n. 1, p.1602-1610, 2008.

SOARES, L. C. O mecanismo e as bases intelectuais da revolução industrial inglesa. Economia, Curitiba, v. 27, n. 1, p. 103-133, 2001.

STEFFENS, J. H. James Prescott Joule and the concept of energy. New York: Dawson Science History Publications, 1979, 172 p. 